\title{
METABOLIC REACTIONS TO ACIDOSIS PRODUCED BY AMMONIUM CHLORIDE
}

\author{
BY \\ NOAH MORRIS, M.D., B.Sc., \\ and
}

OLIVE MacRAE, M.B., Ch.B. (Faulds Fellow in Medicine, University of Glasgow.)

(From the Department of Pædiatrics, Glasgow University, and the Biochemical Department, Royal Hospital for Sick Children, Glasgow.)

Acidosis is so frequently put forward as the underlying pathological condition in such a variety of disorders that it is important to appreciate what actually are the metabolic manifestations of the acidotic state. Clinically one seldom if ever has an opportunity of 'studying acidosis uncomplicated by some such other factor as inanition or toxæmia. It is therefore advisable in an investigation of the metabolic reactions to a disturbance in acid-base equilibrium to have these secondary factors as far as possible excluded. This can only be done when the acidosis is induced in a healthy individual with the minimal amount of upset especially as regards food-intake, and such a condition is most nearly attained in the acidosis produced by the ingestion of ammonium chloride. Haldane ${ }^{1}$ was the first to show that ammonium chloride taken in large amounts led to a marked acidosis owing to its ammonium moiety being converted to urea. Since then many papers have been published dealing with changes following the administration of this substance.

The present research was undertaken primarily with the object of studying the changes in mineral metabolism during acidosis and, if possible, of correlating these changes with other metabolic phenomena. Most workers are agreed that there is an increased output of lime in the urine during acidosis. The effect on the fæcal excretion of lime and the influence of the acidotic state on phosphorus metabolism have not, however, been clearly determined. Steenbock, Nelson and Hart ${ }^{2}$ have pointed out the detrimental effect of acid-forming diets on calcium retention and calcification in animals. Sawyer, Bauman and Stevens ${ }^{3}$ found an increased urinary output of calcium and phosphorus in two children during a period of high fat intake : in only one, however, was there an increase in the fæcal amounts of these substances, while in the other there was a decrease. In a study of acid and base-forming diets in adult women Bogert and Kirkpatrick $^{4}$ did not obtain a constant change in the amount of fæcal calcium during the period of acid-forming diet although the urinary lime was always increased. 
In infants Flood ${ }^{5}$ found that administration of $\mathrm{N} / 10 \mathrm{HCl}$ led to no alteration in the retention of calcium, although this substance always appeared in slightly increased amount in the urine. An accurate knowledge of the changes occurring in mineral metabolism during acidosis would, for instance, be invaluable in throwing further light on the pathogenesis and chemical pathology of such a condition as rickets. Freudenberg and Gyorgy ${ }^{6}$ claim, indeed, that the fundamental factor in the hindrance of calcification in this disease is an increased acidity of the tissue fluids which prevents the precipitation of calcium salts.

It has been shown by Haldane ${ }^{1}$, and Gamble, Ross and Tisdall ${ }^{7}$ that salts such as calcium and ammonium chloride produce their diuretic effect in virtue of their acid-producing powers. This relationship between water-loss and acidosis has frequently been commented upon in states of dehydration accompanying gastro-enteritis. The opportunity was therefore taken in this study to attempt a correlation between the various metabolic changes following on the production of an acidosis by ammonium chloride administration. Gamble, Blackfan and Hamilton ${ }^{8}$, and Følling ${ }^{9}$ have shown the close relationship between the extra loss of water by the kidney and the excess excretion of fixed base. In this research it is hoped to bring forward evidence as to the part played by calcium and phosphorus.

\section{Present investigations.}

The subjects of the study were four apparently normal children-N.G., female aged 11 years ; W.C., male, aged 9 years ; N.M., female aged 10 years ; and J.F., male, aged $9 \frac{1}{4}$ years. Each had recovered from a mild attack of rheumatism. The diet throughout the period of the investigation was constant, consisting of cow's milk with sugar sufficient to satisfy the caloric requirements of the child. After at least three days on the arranged diet the urine and fæces were collected with the usual precautions for periods of seven or six days as stated. Thereafter $1 \mathrm{grm}$. of ammonium chloride was administered 5 times daily in capsule form. The excreta were again collected for a period of 7 days. In the case of N.M. and J.F. the ammonium chloride was continued so as to include a third period of 5 and 6 days respectively. In the case of N.M. $1 \mathrm{drm}$. of cod-liver oil was given thrice daily during this last period.

The individual metabolic changes will first of all be discussed separately. Thereafter an attempt will be made to correlate the various findings with special reference to the defence of the organism against acidosis.

Clinical features.- No apparent change was produced in the appearance of any of the children during or following the ingestion of the ammonium chloride. In two cases the administration continued for a period of eighteen days without any sign of circulatory disturbance. The daily intake varied from $0 \cdot 166$ to $0 \cdot 247 \mathrm{grm}$. per kgrm. of body weight. Haldane produced in himself marked respiratory distress by taking one dose of $25 \mathrm{grm}$. of ammonium chloride, equivalent to $0.25 \mathrm{grm}$. per $\mathrm{kgrm}$. of body weight. Koehler ${ }^{10}$ found that administration of 10-15 grm. of ammonium chloride daily to well-developed adults produced definite symptoms of listlessness, thirst, diuresis and muscular 
aches : these subjects, however, were all patients recovering or recovered from lead-poisoning. Three explanations may be offered for the difference between our results and those recorded elsewhere. First, children may not be as susceptible as adults to the action of ammonium chloride. It is well known that children tolerate a much larger dose per kilogramme of body weight than adults of such a drug as salvarsan. It seems strange, however, that this should be the case with an acid-producing substance when the peculiar susceptibility of the young to disturbances of acid-base equilibrium is remembered. Secondly, the difference in the diets of our subjects and those of the adults may be of importance since milk contains an excess of fixed base over mineral acid. It is possible that this excess base enabled our subjects to withstand the acidosis more effectively than would otherwise have been the case. Thirdly, the division of the daily dose into five portions may have allowed the compensating reactions of the body to come into play before there was any necessity for visible extra effort on the part of the respiratory or other system. It seems to us that the last is the most likely explanation; but whatever the cause may have been, the absence of clinical manifestations of acidosis in no way invalidates this study for, as we shall show later, the blood analyses were indicative of a disturbance of the acid-base equilibrium towards the acid side. Our principal object was to study the changes over a period of at least several days, and it would have been manifestly impossible to have accomplished this in the presence of respiratory distress or other evidence of acute acidosis.

Changes in chemical composition of the blood.-The changes in the chemical composition of the blood found during the ammonium chloride period are in close agreement with those reported by Haldane ${ }^{1}$, and Gamble, Blackfan and Hamilton ${ }^{8}$. The changes in the individual constituents will be discussed in turn.

a. Carbon dioxide. (See Table 1, column 1.) The total $\mathrm{CO}_{2}$ of the blood was reduced in every case. Keith and Whelan ${ }^{11}$ found that the plasma $\mathrm{CO}_{2}$ dropped about the 4th or 5th day of the administration of ammonium chloride. In the last three subjects the $\mathrm{CO}_{2}$ content was estimated two or more times during the ammonium chloride period. From these results it is evident that the reduction in the $\mathrm{CO}_{2}$ content reached what was practically its maximum, comparatively early in the reaction to ammonium chloride. Continued administration of the acid-producing substance had but little further effect on the $\mathrm{CO}_{2}$ content of the blood. This is probably due to the fact that the other regulating mechanisms came into play, and thus protected the $\mathrm{CO}_{2}$ contents, and almost certainly the $\mathrm{pH}$, from further reduction. Accordingly, if in any case the $\mathrm{CO}_{2}$ content of the blood persistently falls from day to day, it would indicate that the other regulating reactions are unable to cope with the amount of acid produced.

B. Chlorine. (See Table 1, column 2.) The chlorine was moderately increased. The increase in chlorine when calculated in milli-equivalents of bicarbonate (Table 2) did not compensate for the decrease in milli-equivalents of bicarbonate. Baird, Douglas, Haldane and Priestley ${ }^{12}$ found that the carbonate ion of the plasma and tissues is partly replaced by the chlorine ion in 
TABLE 1.

Changes in chemical composition of blood.

\begin{tabular}{|c|c|c|c|c|c|c|c|c|}
\hline \multirow[t]{2}{*}{ Name } & \multirow{2}{*}{\multicolumn{2}{|c|}{ Stage }} & (1) & (2) & (3) & (4) & (5) & (6) \\
\hline & & & $\begin{array}{c}\mathrm{CO}_{2} \\
\text { Vol. \% }\end{array}$ & $\begin{array}{c}\mathrm{Cl}^{\prime} \\
\text { mgrm. } \%\end{array}$ & $\begin{array}{c}\text { Fixed base } \\
\text { c.cm. } \\
\text { N } / 10 \%\end{array}$ & $\begin{array}{c}\text { N.P.N. } \\
\text { mgrm. \% }\end{array}$ & $\begin{array}{c}\text { Calcium } \\
\text { mgrm. \% }\end{array}$ & $\begin{array}{c}\text { Phosphorus } \\
\text { mgrm. \% }\end{array}$ \\
\hline N.G. & & $\begin{array}{l}\text { ormal } \quad \ldots \\
\text { days } \mathrm{NH}_{4} \mathrm{Cl}\end{array}$ & $\begin{array}{l}55 \cdot 1 \\
38 \cdot 7\end{array}$ & $\begin{array}{l}300 \\
350\end{array}$ & $\begin{array}{l}158 \\
154\end{array}$ & $\begin{array}{l}36 \cdot 5 \\
46 \cdot 1\end{array}$ & $\overline{-}$ & - \\
\hline W.c. & & $\begin{array}{c}\text { ormal } \ldots \\
\text { days } \mathrm{NH}_{4} \mathrm{Cl} \\
" \# \#\end{array}$ & $\begin{array}{l}68 \cdot 2 \\
41 \cdot 4 \\
40 \cdot 3\end{array}$ & $\begin{array}{l}340 \\
360 \\
340\end{array}$ & $\begin{array}{l}148 \\
157 \\
157\end{array}$ & $\frac{37}{44}$ & $\begin{array}{c}10 \cdot 6 \\
\frac{1}{10 \cdot 1}\end{array}$ & $\frac{5 \cdot 2}{6 \cdot 5}$ \\
\hline J.F. & & $\begin{array}{cc}\text { ormal } & \ldots \\
" & " \\
" & "\end{array}$ & $\begin{array}{l}66 \cdot 7 \\
49 \cdot 1 \\
45 \cdot 8\end{array}$ & $\begin{array}{l}240 \\
360 \\
320\end{array}$ & $\begin{array}{l}154 \\
159 \\
154\end{array}$ & $\begin{array}{l}35 \cdot 5 \\
48 \cdot 5 \\
40 \cdot 1\end{array}$ & $\begin{array}{l}9 \cdot 1 \\
9 \cdot 1 \\
8 \cdot 80\end{array}$ & $\begin{array}{l}- \\
-\end{array}$ \\
\hline N.M. & $\begin{array}{r}N \\
3 \\
6 \\
9 \\
13\end{array}$ & $\begin{array}{cc}\text { ormal } & \ldots \\
\text { days } & \mathrm{NH}_{4} \mathrm{Cl} \\
" & \cdot \\
" & " \\
" & "\end{array}$ & $\begin{array}{l}60 \cdot 6 \\
45 \cdot 1 \\
41 \cdot 8 \\
43 \cdot 4 \\
41 \cdot 5\end{array}$ & $\begin{array}{l}285 \\
290 \\
- \\
280 \\
320\end{array}$ & $\begin{array}{l}147 \\
- \\
132 \\
137\end{array}$ & $\begin{array}{l}35 \\
- \\
46 \\
32\end{array}$ & $\begin{array}{l}9 \cdot 25 \\
- \\
9 \cdot 8 \\
-\end{array}$ & $\begin{array}{l}4 \cdot 2 \\
\overline{-} \\
4 \cdot 1 \\
-\end{array}$ \\
\hline
\end{tabular}

TABLE 2.

SHOWING COMPENSATORY DECREASE AND INCREASE OF CHLORINE AND BICARBONATE IONS RESPECTIVELY.

\begin{tabular}{|c|c|c|c|c|c|c|}
\hline Name & Stage & $\begin{array}{l}\mathrm{HCO}_{3}^{\prime} \\
\text { c.cm. } \\
\mathrm{N} / 10 \%\end{array}$ & $\begin{array}{c}\mathrm{Cl}^{\prime} \\
\text { c.cm. } \\
\mathrm{N} / 10 \%\end{array}$ & $\begin{array}{c}\mathrm{HCO}_{3}^{\prime}+\mathrm{Cl}^{\prime} \\
\text { c.cm. } \\
\mathrm{N} / 10 \%\end{array}$ & $\begin{array}{c}\text { Change of } \\
\mathrm{HCO}^{\prime}{ }_{3} \& \mathrm{Cl}^{\prime} \\
\text { from normal }\end{array}$ & $\begin{array}{l}\text { Change in } \\
\text { fixed } \\
\text { base }\end{array}$ \\
\hline N.G. & $\begin{array}{l}\text { Normal } \ldots \\
7 \text { days } \mathrm{NH}_{4} \mathrm{Cl}\end{array}$ & $\begin{array}{l}24 \cdot 6 \\
17 \cdot 3\end{array}$ & $\begin{array}{l}84 \cdot 5 \\
98 \cdot 6\end{array}$ & $\begin{array}{l}109 \cdot 1 \\
115 \cdot 9\end{array}$ & $\overline{+6 \cdot 8}$ & $\overline{-4}$ \\
\hline W.c. & $\begin{array}{l}\text { Normal } \ldots \\
4 \text { days } \mathrm{NH}_{4} \mathrm{Cl} \\
8 \# \quad \#\end{array}$ & $\begin{array}{l}30 \cdot 4 \\
18 \cdot 5 \\
18 \cdot 0\end{array}$ & $\begin{array}{r}95 \cdot 7 \\
101 \cdot 4 \\
95 \cdot 7\end{array}$ & $\begin{array}{l}126 \cdot 1 \\
119 \cdot 9 \\
113 \cdot 7\end{array}$ & $\begin{array}{c}-\overline{6} \\
-6 \cdot 2 \\
-12 \cdot 4\end{array}$ & $\begin{array}{l}- \\
+9 \\
+9\end{array}$ \\
\hline J.F. & $\begin{array}{l}\text { Normal } \ldots \\
9 \text { days } \mathrm{NH}_{4} \mathrm{Cl} \\
19 \quad " \quad, \quad "\end{array}$ & $\begin{array}{l}29 \cdot 8 \\
21 \cdot 9 \\
20 \cdot 4\end{array}$ & $\begin{array}{r}70.0 \\
101 \cdot 4 \\
90 \cdot 1\end{array}$ & $\begin{array}{r}99 \cdot 8 \\
123 \cdot 3 \\
110 \cdot 5\end{array}$ & $\begin{array}{l}-\overline{-} \\
+23 \cdot 5 \\
+10 \cdot 7\end{array}$ & $\begin{array}{r}- \\
+5 \\
0\end{array}$ \\
\hline N.M. & $\begin{array}{l}\text { Normal } \\
3 \text { days } \mathrm{NH}_{4} \mathrm{Cl} \\
9 \Rightarrow, \quad " \\
13 \quad, \quad "\end{array}$ & $\begin{array}{l}27 \cdot 1 \\
20 \cdot 1 \\
19 \cdot 4 \\
18 \cdot 5\end{array}$ & $\begin{array}{l}80 \cdot 3 \\
81 \cdot 7 \\
80 \cdot 3 \\
90 \cdot 1\end{array}$ & $\begin{array}{r}107 \cdot 4 \\
101 \cdot 8 \\
99 \cdot 7 \\
108 \cdot 6\end{array}$ & $\begin{array}{r}- \\
-5 \cdot 6 \\
-7 \cdot 7 \\
+1 \cdot 2\end{array}$ & $\begin{array}{l}- \\
-15 \\
-10\end{array}$ \\
\hline
\end{tabular}


conditions of acidosis. Gamble, Blackfan and Hamilton ${ }^{8}$ also reported similar results with both $\mathrm{NH}_{4} \mathrm{Cl}$ and $\mathrm{CaCl}_{2}$. In our cases, however, this replacement was by no means exact even when allowance was made for the change in fixed base. In W.C. there was an actual increase in fixed base accompanied by a deficit in the sum of bicarbonate and chloride. In J.F., on the other hand, the increase in chloride over-compensated the loss in bicarbonate: in this case the control period was characterized by a very low chlorine content. An objection may be raised that these analyses were performed on whole blood and not on plasma, but it should be remembered that the cell walls are equally permeable to chlorine and carbonic acid. It would seem, therefore, that all the acid ions take part in mutual compensation. As will be indicated later, there is but little change in the inorganic phosphorus of the blood. Indeed, the possible limits of the amounts of this substance and sulphate render a change in either almost negligible as a compensatory factor. It is probable that the organic acids of the blood play an important part in balancing excess or deficit of the other acids, as has been suggested by Gamble and his co-workers in alkalosis resulting from experimental obstruction of the pylorus. We have no data on the change in base-combining power of the plasma proteins, but the findings of Keith and Whelan ${ }^{11}$, and Følling ${ }^{9}$ suggest that such change is trifling.

c. Fixed Base. (See Table 1, column 3.) Gamble, Blackfan and Hamilton ${ }^{8}$ state that there is a very slight reduction in the fixed base cf the serum, and Følling reports a fall of $\mathbf{1 5 . 4}$ milli-equivalents per litre. In two of our cases there was a decrease in the fixed base content of the serum : in one of these (N.M.) the reduction amounted to 15 milli-equivalents per litre, resulting in a value outside the normal limits. In the other two cases there was an increase in fixed base but the raised values fell within normal limits.

D. Calcium and Phosphorus. (See Table 1, columns 5 and 6.) In 1924 Stewart and Haldane ${ }^{13}$ noted a 10 per cent. rise in the serum calcium of a healthy adult, following the administration of $25 \mathrm{grm}$. $\mathrm{NH}_{4} \mathrm{Cl}$. Haldane, Wigglesworth and Woodrow ${ }^{14}$ found no significant change in the inorganic phosphorus of the serum during acidosis but observed a slight fall as the acidosis was passing off. In the results recorded in Table 1, where the estimations were made after a variable period from the commencement of the acidosis, no constant change in either calcium or phosphorus was observed. In the other two subjects (Fig. 1 and 2) more frequent analyses were made. In both, the serum calcium showed an initial rise which persisted till the fifth day, thereafter falling below the normal level: on the cessation of ammonium chloride administration the calcium immediately rose somewhat above the ' control' level and then returned to normal. The serum phosphorus moved in the inverse direction to calcium.

e. Non-protein Nitrogen. (See Table 1, column 4.) In every case this was found to be increased. In the two cases in which it was determined twice during the administration of ammonium chloride, the value had fallen at the second estimation. 


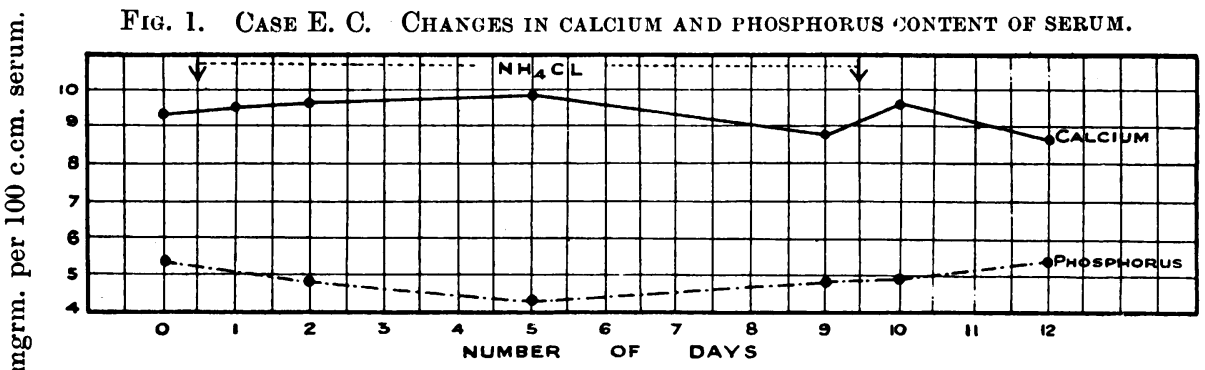

Fig. 2. Case A. M. Changes in calcium and phosphorus content of serum.

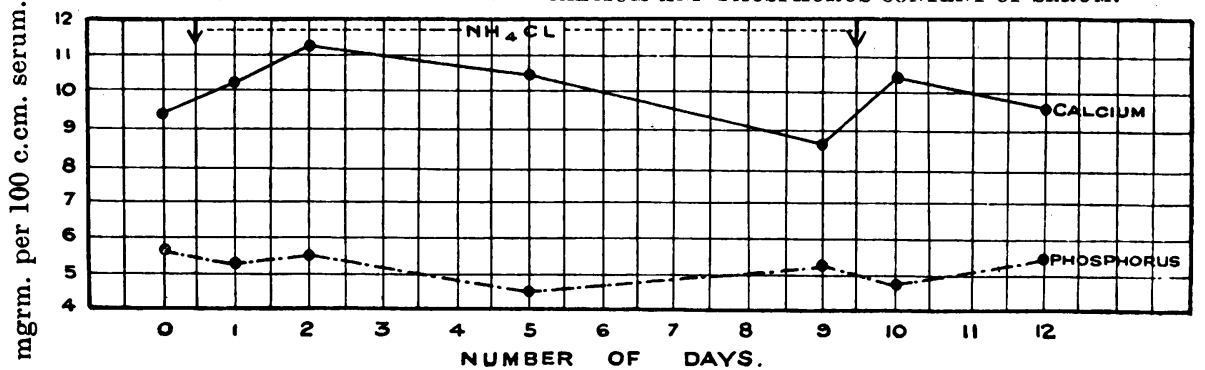

Keith and Whelan ${ }^{11}$ have shown that there is no increase in the ammonia content of the blood after ingestion of ammonium chloride. In our cases if the increase in non-protein nitrogen had been due to ammonia there would have been a rise in the ammonia value of from 8.5 to $15.8 \mathrm{mgrm}$. per cent.

TABLE 3.

Blood analyses in CaSes of clinical acidosis.

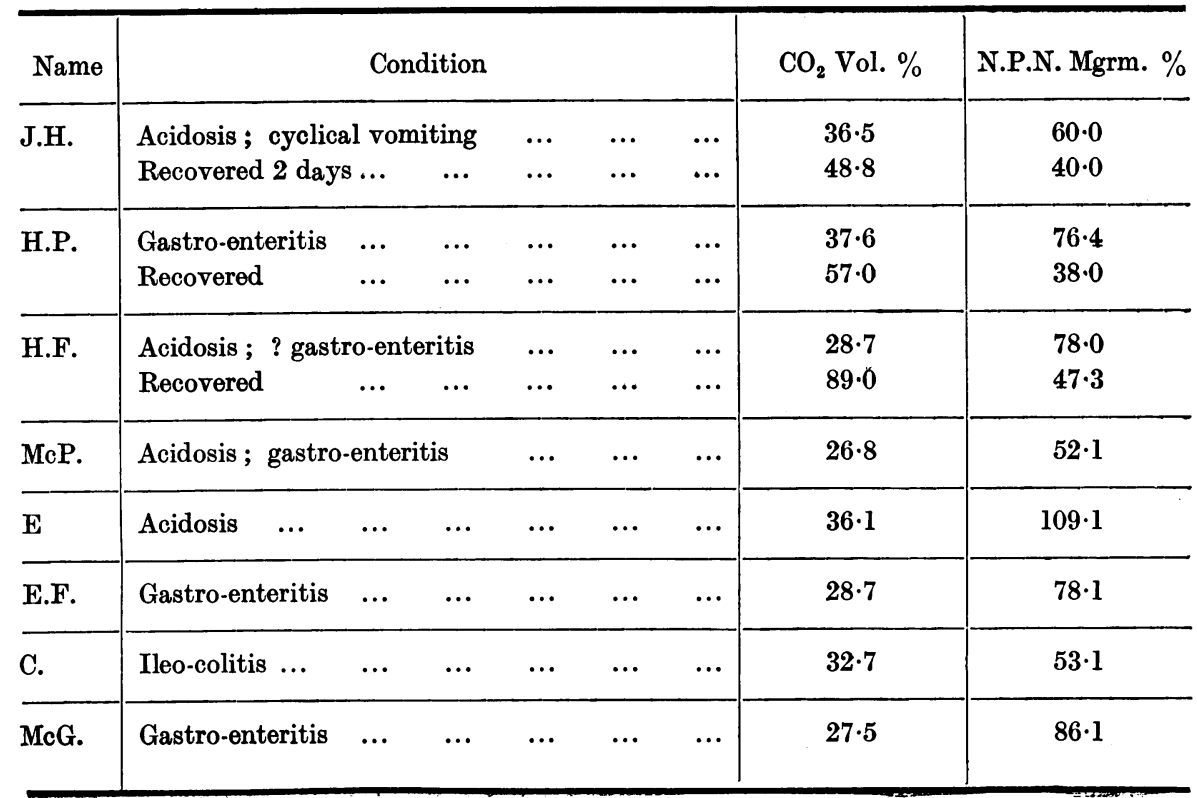


Such an amount of circulating ammonia would almost certainly have produced marked symptoms of poisoning, as ammonia is a very toxic substance. It is therefore highly improbable that the increase in non-protein nitrogen is due to ammonia nitrogen. A more reasonable explanation is that the rise is the result of increased breakdown of tissue proteins consequent on the disturbance of acid-base equilibrium. This view is supported by blood analyses in some cases of frank clinical acidosis (Table 3). It will be seen that in three cases during the stage of acidosis the non-protein nitrogen was increased, to fall to normal in the post-acidotic period. In cases of alkalosis where it also rises, the suggestion has been put forward that the cause is renal inefficiency. This can hardly have been the case in our subjects since, as will be seen later, there was a definite increase in the urinary output of ammonia, a good indication of unimpaired renal function.

Metabolism of calcium and phosphorus.--The intake and output of calcium and phosphorus in each case is detailed in Table 4 which also shows the retention and the partition of these substances between urine and fæces. In Table $\tilde{5}$ are given the results of the fæcal analyses for calcium, phosphorus and fat.

It will be convenient to give a brief account of the results in each case, and thereafter to summarize and discuss the bearing of these findings on the general problem of mineral metabolism.

TABLE 4.

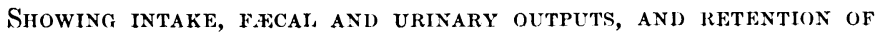
CALCIIM ANI) PHOSPHORUS (GRM.).

\begin{tabular}{|c|c|c|c|c|c|c|c|c|c|c|c|c|c|c|}
\hline \multirow[t]{2}{*}{ Name } & \multicolumn{2}{|c|}{ Period } & \multicolumn{2}{|c|}{ Total intake } & \multicolumn{2}{|c|}{ Fæcal output } & \multicolumn{2}{|c|}{ Urinary output } & \multicolumn{2}{|c|}{$\begin{array}{l}\% \text { of total } \\
\text { output in } \\
\text { urine }\end{array}$} & \multicolumn{2}{|c|}{$\begin{array}{c}\text { Total } \\
\text { Retention }\end{array}$} & \multicolumn{2}{|c|}{$\begin{array}{l}\text { Retention per } \\
\text { kgrm. per day }\end{array}$} \\
\hline & Intake & Days & $\mathrm{CaO}$ & $\mathrm{P}_{2} \mathrm{O}_{5}$ & $\mathrm{CaO}$ & $\mathrm{P}_{2} \mathrm{O}_{5}$ & $\mathrm{CaO}$ & $\mathrm{P}_{2} \mathrm{O}_{5}$ & $\mathrm{CaO}$ & $\mathrm{P}_{2} \mathrm{O}_{5}$ & $\mathrm{CaO}$ & $\mathrm{P}_{2} \mathrm{O}_{5}$ & $\mathrm{CaO}$ & $\mathrm{P}_{2} \mathrm{O}_{5}$ \\
\hline N.G. & $\begin{array}{l}\text { Normal } \\
\mathrm{NH}_{4} \mathrm{Cl}\end{array}$ & $\begin{array}{l}7 \\
7\end{array}$ & $\begin{array}{l}20 \cdot 16 \\
20 \cdot 16\end{array}$ & $\begin{array}{l}27 \cdot 72 \\
27 \cdot 72\end{array}$ & $\begin{array}{r}9 \cdot 508 \\
12 \cdot 445\end{array}$ & $\begin{array}{l}6 \cdot 818 \\
8 \cdot 984\end{array}$ & $\begin{array}{l}1 \cdot 406 \\
2 \cdot 949\end{array}$ & $\begin{array}{l}11 \cdot 55 \\
12 \cdot 222\end{array}$ & $\begin{array}{l}12 \cdot 8 \\
19 \cdot 0\end{array}$ & $\begin{array}{l}62 \cdot 8 \\
57 \cdot 6\end{array}$ & $\begin{array}{l}9 \cdot 246 \\
4 \cdot 766\end{array}$ & $\begin{array}{l}9 \cdot 352 \\
6 \cdot 514\end{array}$ & $\begin{array}{l}.05 \\
.025\end{array}$ & $\begin{array}{l}.05 \\
.034\end{array}$ \\
\hline W.C. & $\begin{array}{l}\text { Normal } \\
\mathrm{NH}_{4} \mathrm{Cl}\end{array}$ & $\begin{array}{l}7 \\
7\end{array}$ & $\begin{array}{l}20 \cdot 16 \\
20 \cdot 16\end{array}$ & $\begin{array}{l}27 \cdot 72 \\
27 \cdot 72\end{array}$ & $\begin{array}{l}14 \cdot 983 \\
15 \cdot 938\end{array}$ & $\begin{array}{l}14 \cdot 390 \\
14 \cdot 564\end{array}$ & $\begin{array}{l}1 \cdot 521 \\
2 \cdot 60\end{array}$ & $\begin{array}{r}9 \cdot 464 \\
12 \cdot 600\end{array}$ & $\begin{array}{r}9 \cdot 2 \\
14 \cdot 0\end{array}$ & $\begin{array}{l}39 \cdot 7 \\
46 \cdot 4\end{array}$ & $\begin{array}{l}3 \cdot 66 \\
1 \cdot 62\end{array}$ & $\begin{array}{l}3 \cdot 87 \\
0 \cdot 56\end{array}$ & $\begin{array}{l}.018 \\
.008\end{array}$ & $\begin{array}{l}.019 \\
.002\end{array}$ \\
\hline J.F. & $\begin{array}{l}\text { Normal } \\
\mathrm{NH}_{4} \mathrm{Cl} \\
\mathrm{NH}_{4} \mathrm{Cl}\end{array}$ & $\begin{array}{l}6 \\
6 \\
6\end{array}$ & $\begin{array}{l}13 \cdot 44 \\
13 \cdot 44 \\
13 \cdot 44\end{array}$ & $\begin{array}{l}18 \cdot 48 \\
18 \cdot 48 \\
18 \cdot 48\end{array}$ & $\begin{array}{r}8 \cdot 621 \\
11 \cdot 158 \\
8 \cdot 823\end{array}$ & $\begin{array}{l}7 \cdot 494 \\
9 \cdot 564 \\
7 \cdot 728\end{array}$ & $\begin{array}{l}0 \cdot 683 \\
2 \cdot 133 \\
2 \cdot 099\end{array}$ & $\begin{array}{l}7 \cdot 686 \\
7 \cdot 812 \\
7 \cdot 392\end{array}$ & $\begin{array}{r}7 \cdot 3 \\
16 \cdot 0 \\
19 \cdot 0\end{array}$ & $\begin{array}{l}50 \cdot 6 \\
44 \cdot 9 \\
48 \cdot 9\end{array}$ & $\begin{array}{l}4 \cdot 136 \\
0 \cdot 149 \\
2 \cdot 518\end{array}$ & $\begin{array}{l}3 \cdot 30 \\
1 \cdot 104 \\
3 \cdot 36\end{array}$ & $\begin{array}{l}.034 \\
.001 \\
.021\end{array}$ & $\begin{array}{l}.027 \\
.009 \\
.028\end{array}$ \\
\hline N.M. & $\begin{array}{l}\text { Normal } \\
\mathrm{NH}_{4} \mathrm{Cl} \\
\mathrm{NH}_{4} \mathrm{Cl} \& \\
\text { cod-liver } \\
\text { oil }\end{array}$ & $\begin{array}{l}7 \\
7 \\
5\end{array}$ & $\begin{array}{l}19 \cdot 60 \\
19 \cdot 60 \\
14 \cdot 00\end{array}$ & $\begin{array}{l}26 \cdot 95 \\
26 \cdot 95 \\
19 \cdot 25\end{array}$ & $\begin{array}{l}10 \cdot 959 \\
19 \cdot 649 \\
17 \cdot 799\end{array}$ & $\begin{array}{r}9 \cdot 627 \\
17 \cdot 445 \\
16 \cdot 425\end{array}$ & $\begin{array}{l}1 \cdot 784 \\
3 \cdot 192 \\
2 \cdot 829\end{array}$ & $\begin{array}{l}11 \cdot 102 \\
11 \cdot 928 \\
10 \cdot 212\end{array}$ & $\begin{array}{l}14 \cdot 0 \\
13 \cdot 7 \\
13 \cdot 7\end{array}$ & $\begin{array}{l}53 \cdot 5 \\
40 \cdot 7 \\
38 \cdot 3\end{array}$ & $\begin{array}{r}6 \cdot 857 \\
-3 \cdot 241 \\
--6 \cdot 608\end{array}$ & $\begin{array}{r}6 \cdot 121 \\
-2 \cdot 759 \\
-7 \cdot 387\end{array}$ & $\begin{array}{r}.033 \\
-.015 \\
-.044\end{array}$ & $\begin{array}{r}.029 \\
-.013 \\
-.050\end{array}$ \\
\hline
\end{tabular}


TABLE 5.

Showing ASh, CALCIUM, PHOSPhorus aNd Fat content of Faces.

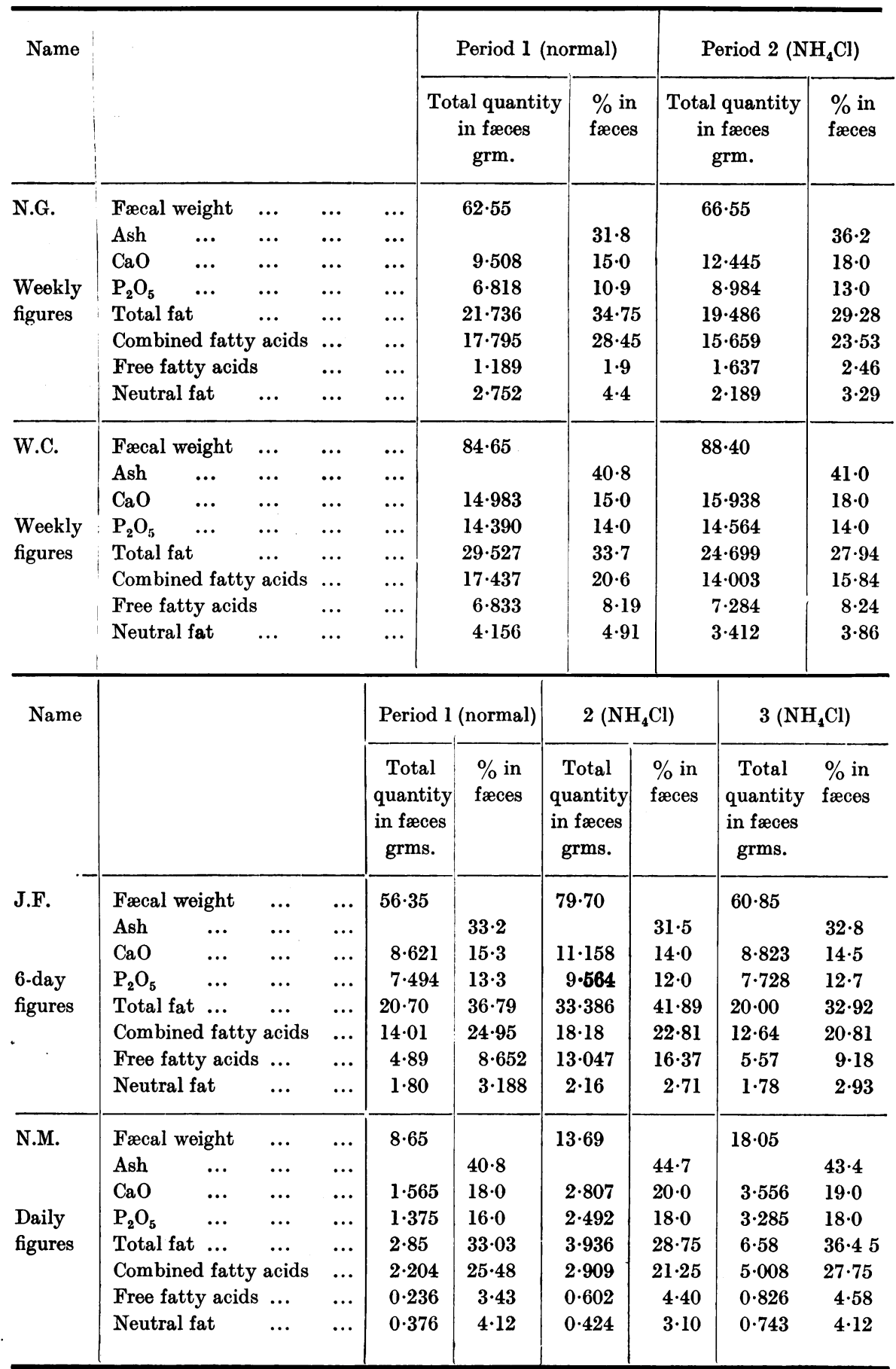


N.G. The retentions of $\mathrm{CaO}$ and $\mathrm{P}_{2} \mathrm{O}_{5}$ were reduced. The output of lime in the fæces was increased as the result of an increased percentage of $\mathrm{CaO}$ in the fæces and also a rise in the weight of the dried fæces. The urinary excretion of lime was also increased. The output of $\mathrm{P}_{2} \mathrm{O}_{5}$ by the urine was likewise raised, but the decreased retention of $\mathrm{P}_{2} \mathrm{O}_{5}$ was mainly the result of an increased fæcal content of this substance. As with lime the rise in fæcal phosphorus was consequent on an increased percentage output together with a rise in the fæcal weight. The percentage of ash was also increased, while the percentage and absolute amounts of total fat and combined fatty acids were decreased.

w.c. The results here were practically identical with those recorded above. One point of difference may be noticed, namely, the fact that there was but little increase in the fæcal output of $\mathrm{P}_{2} \mathrm{O}_{5}$, the lowering of the retention value being due to a fairly marked rise in the urinary content.

J.F. In this case there were two successive periods on $\mathrm{NH}_{4} \mathrm{Cl}$. The retentions of $\mathrm{CaO}$ and $\mathrm{P}_{2} \mathrm{O}_{5}$ were reduced during the first of the two periods but returned practically to normal in the second. There was a rise in the urinary $\mathrm{CaO}$ in both periods, and the urinary $\mathrm{P}_{2} \mathrm{O}_{5}$ in each was practically unchanged. The reduced retentions of lime and phosphorus were due entirely to the increased fæcal output resulting from a rise in the fæcal weight; the percentages of ash, calcium and phosphorus were all reduced. The percentage of total fat in the fæces was increased during the first period because of the marked increase in free fatty acids, while in the second period the value for total fat was slightly below that of the normal. The percentage of combined fatty acid was reduced during both periods.

N.M. With this subject there were two periods on $\mathrm{NH}_{4} \mathrm{Cl}$, the first for 7 days and the second for 5 days during which time one dram of cod-liver oil was given three times daily in addition. A negative balance of both lime and phosphorus was found during each $\mathrm{NH}_{4} \mathrm{Cl}$ period, being much more marked on the second. The urinary output of lime and phosphorus was increased on both occasions, the increase in urinary phosphorus being much more marked in the second of the two periods. The percentages of lime phosphorus and ash in the fæces were increased, but the marked rise in the total fæcal output of $\mathrm{CaO}$ and $\mathrm{P}_{2} \mathrm{O}_{5}$ was chiefly the result of the striking increase in the weight of dried fæces. In the first period the percentages of total fat and combined fatty acids were reduced but in the second, during which cod-liver oil was also administered, these percentages were increased slightly above those outlined in the normal period.

Summary.-There was in all cases a reduced retention of lime and phosphorus resulting from an increased output of these substances in both urine and fæces.

(a). Calcium.-Goto ${ }^{15}$ found in acidosis an increased excretion of calcium by the urine but Keith and Whelan ${ }^{11}$ observed but little change in the urinary excretion of calcium during administration of ammonium chloride. In our cases, however, the urinary calcium was at least doubled and in one instance trebled. The increased fæcal excretion of calcium was due to an increase in the total fæcal weight and, with the exception of J.F., an increase in the percentage of lime in the fæces. Generally the increase in fæcal calcium was much greater than that obtained in the urine. In W.C., however, the urinary and fæcal increases were approximately equal, and in J.F. (2nd period) the urinary increase exceeded that in the fæces.

(b). Phosphorus.-The extra output of phosphorus was even less consistently distributed between urine and fæces than was the extra lime. In only one case (W.C.) was the increase in urinary phosphorus marked. Apart from this case, in which the rise in fæcal phosphorus was insignificant, the main increase in excretion was by the fæces.

(c). Weight of dried fæces.-In all cases there occurred an increase. 
(d). Ash.-With the exception of J.F. (1st period) there was always a rise in the percentage of ash in the dried fæces.

(e). Fæcal fat.- The percentage of total fat in the fæces was reduced in all cases except J.F. (1st period) and N.M. (2nd period). The percentage of combined fatty acids was reduced in all cases except N.M. (2nd period).

Discussion.--In spite of the large amount of work done in connection with calcium metabolism there is as yet no definite information as to the extent of absorption of this element, and it is still a matter for conjecture how much of the fæcal calcium has been absorbed and excreted through the bowel wall, and how much has passed through the gut unabsorbed. Grosser ${ }^{16}$ found that subcutaneous injection of calcium salts led to an increased excretion by the bowel, and Salvesen ${ }^{17}$ showed that in parathyroidectomized dogs, of calcium chloride injected intravenously, nine-tenths was excreted in the fæces and one-tenth in the urine. Percival and Stewart ${ }^{18}$ isolated the large intestine in cats and found that the intravenous administration of calcium chloride was followed by a marked increase in the excretion of calcium by the large intestine, but no change in the urinary output. Recently Bauer, Allbright and Aub' ${ }^{10}$ have published the results of an investigation of the calcium metabolism on a very low calcium intake in 13 normal adults. On these 13 subjects there were 46 three-day periods of investigation. With the exception of a single period in one case, they found in all a negative balance of calcium, and with the exception of three periods there occurred in the fæces a greater amount of lime than had been ingested. In one case (N.M.) of our series during each of two periods on ammonium chloride there was a greater amount of calcium in the fæces than had been ingested. From these results it is justifiable to conclude that in ammonium-chloride acidosis excretion of calcium through the bowel wall can occur. Our results also contradict the statement of Givens and Mendel $^{20}$ that the increase in urinary calcium in acidosis is the result of diversion of lime from stools to urine. In our cases both the urinary and fæcal lime was increased in amount.

In one period at least (N.M., 2nd period) there was unequivocal evidence of calcium excretion by the bowel wall. Since, however, there was no alteration in the lumen of the gut other than the temporary presence of ammonium chloride which we shall show was practically completely absorbed, it seems reasonable to assume that absorption of lime was unaltered during the ammonium chloride period. The excess of fæcal calcium must therefore have been the result of excretion by the bowel wall. On similar grounds it would appear that the excess of fæcal phosphorus in the ammonium chloride period was the result, not of decreased absorption, but of increased excretion through the wall of the intestine.

The investigations of Nelson ${ }^{21}$ on the mineral metabolism of patients suffering from diabetes and of epileptic subjects fed on ketogenic diets have shown that the kidneys are capable of excreting large amounts of lime. Indeed, more than half the total excretion of calcium may take place through the urinary system. In these cases there is also a slight increase in the fæcal output of lime. The presence of an acidosis, therefore, leads to an increased 
excretion of lime both by urine and fæces. In our series, with the exception of N.M., the percentage of lime excreted by the urine is always increased during the ammonium chloride period. This would suggest that the amount of calcium excreted by the kidneys is to some extent dependent on the degree of acidosis. Additional support would at first glance seem to be lent to this view by the results of Shohl and Sato ${ }^{22}$, and Bogert and Kirkpatrick ${ }^{4}$. The former found that the addition of sodium bicarbonate to the diet decreased the urinary output of $\mathrm{CaO}$ and $\mathrm{P}_{2} \mathrm{O}_{5}$, but increased their content in the fæces to such an extent that the retention of each was reduced. Bogert and Kirkpatrick record similar results with a base-forming diet. The addition of sodium bicarbonate to the diet brings in another factor, namely, a change in the reaction of the lumen of the gut. The decreased urinary output of calcium during administration of bicarbonate may be entirely due to the local effect of this salt in interfering with the absorption of lime by increasing the $\mathrm{pH}$ of the intestinal contents.

Freudenberg and György ${ }^{6}$ have advanced the theory that the decreased retention of calcium in rickets is due to an acidosis of the tissues which interferes with the precipitation of calcium salts. If this view were correct one would expect the mode of excretion of lime and phosphorus to be similar to that found during ammonium chloride acidosis. Quite the reverse obtains, since the output of lime in the urine is markedly diminished, as is also the urinary phosphorus; and the very low retention of these minerals is caused entirely by the large fæcal content of $\mathrm{CaO}$ and $\mathrm{P}_{2} \mathrm{O}_{5}$. In other words, the partition of calcium and phosphorus in the excreta in rickets closely resembles that found in conditions tending to alkalosis rather than acidosis.

TABLE 6.

Showing intake, output and Retention of Chlorine (c.cm. N/10 (1).

\begin{tabular}{|c|c|c|c|c|c|c|c|c|}
\hline \multirow{2}{*}{ Name } & \multirow{2}{*}{\multicolumn{3}{|c|}{ Period }} & \multirow{2}{*}{ Intake } & \multicolumn{2}{|c|}{ Output } & \multicolumn{2}{|c|}{ Retention } \\
\hline & & & & & Urine & Fæces & Total & $\begin{array}{l}\text { Per kgrm. } \\
\text { per day }\end{array}$ \\
\hline N.G. & $\begin{array}{l}\text { Normal ... } \\
\mathrm{NH}_{4} \mathrm{Cl} \ldots\end{array}$ & $\begin{array}{l}\cdots \\
\cdots\end{array}$ & $\begin{array}{l}\cdots \\
\cdots\end{array}$ & $\begin{array}{r}4133 \\
10675\end{array}$ & $\begin{array}{l}3585 \\
9518\end{array}$ & $\begin{array}{l}36 \\
40\end{array}$ & $\begin{array}{l}+512 \\
+1117\end{array}$ & $\begin{array}{l}+2 \cdot 8 \\
+6 \cdot 1\end{array}$ \\
\hline W.C. & $\begin{array}{l}\text { Normal ... } \\
\mathrm{NH}_{4} \mathrm{Cl} \ldots\end{array}$ & $\begin{array}{l}\cdots \\
\cdots\end{array}$ & $\begin{array}{l}\cdots \\
\cdots\end{array}$ & $\begin{array}{r}4133 \\
10675\end{array}$ & $\begin{array}{l}3815 \\
9853\end{array}$ & $\begin{array}{l}15 \\
17\end{array}$ & $\begin{array}{l}+303 \\
+805\end{array}$ & $\begin{array}{l}+1 \cdot 6 \\
+4 \cdot 3\end{array}$ \\
\hline J.F. & $\begin{array}{ll}\text { Normal ... } \\
\mathrm{NH}_{4} \mathrm{Cl} & \ldots \\
\mathrm{NH}_{4} \mathrm{Cl} & \ldots\end{array}$ & $\begin{array}{l}\cdots \\
\cdots \\
\cdots\end{array}$ & $\begin{array}{l}\cdots \\
\cdots \\
\cdots\end{array}$ & $\begin{array}{l}2755 \\
8365 \\
8365\end{array}$ & $\begin{array}{l}2829 \\
7299 \\
7656\end{array}$ & - & $\begin{array}{l}-74 \\
+1066 \\
+709\end{array}$ & $\begin{array}{l}-0.6 \\
+8.8 \\
+5.8\end{array}$ \\
\hline N.M. & $\begin{array}{r}\text { Normal ... } \\
\mathrm{NH}_{4} \mathrm{Cl} \quad \ldots \\
\mathrm{NH}_{4} \mathrm{Cl} \\
\quad \ldots \\
(5 \text { days })\end{array}$ & $\begin{array}{l}\cdots \\
\cdots \\
\cdots\end{array}$ & $\begin{array}{l}\cdots \\
\cdots \\
\cdots\end{array}$ & $\begin{array}{r}4018 \\
10560 \\
7545\end{array}$ & $\begin{array}{r}3706 \\
10040 \\
7678\end{array}$ & $\begin{array}{l}- \\
-\end{array}$ & $\begin{array}{l}+312 \\
+635 \\
-133\end{array}$ & $\begin{array}{l}+1.5 \\
+3.0 \\
-0.9\end{array}$ \\
\hline
\end{tabular}


Chlorine.-The excretion of chloride normally takes place through the urine and the sweat. The fæcal output is practically negligible. It was estimated in two of our cases, and as will be seen from the results in Table 6 the fæcal excretion of chloride was relatively minute both during the control and ammonium chloride periods.

During the control period there was a small retention of chlorine except in the case of J.F. where there was a very slight negative balance. While ammonium chloride was being administered the retention was increased in every case except during the second period of N.M., which was characterized by a slight negative balance.

TABLE 7.

Perchntage nXcretion of Chlorine In First 24 hours following INGESTION OF SODIUM CHLORIDE.

\begin{tabular}{c|c|c|c}
\hline Amt. of $\mathrm{NaCl}$ given & $\begin{array}{c}\text { Form in which } \\
\mathrm{NaCl} \text { given }\end{array}$ & Diet & $\begin{array}{c}\text { \% Excetion of extra salt } \\
\text { during lst 24 hr. }\end{array}$ \\
\hline $4 \cdot 5$ & Saline & Salt poor & 53 \\
$4 \cdot 5$ & Saline & Salt rich & 62 \\
$10 \cdot 0$ & Salt poor & 50 \\
$10 \cdot 0$ & Solid in capsule & Salt rich & 67 \\
\hline
\end{tabular}

When one comes to examine the daily figures it is plain that all the subjects reacted immediately to the extra chlorine by the excretion of a greatly increased amount of this substance in the urine. In N.G. the output was doubled on the first day, so that only about 30 per cent. of the extra chlorine had been retained. This corresponds to what happens when sodium chloride is given. Table 7 indicates the percentage excretion of chlorine in the first 24 hours following ingestion of sodium chloride: the subject was a healthy boy aged 11 years.

Fig. 3. Case N. (4. Graph showing daily urinary output of water. CHLORINE, FIXED BASE, AMMONIA AND TITRATABLE ACID

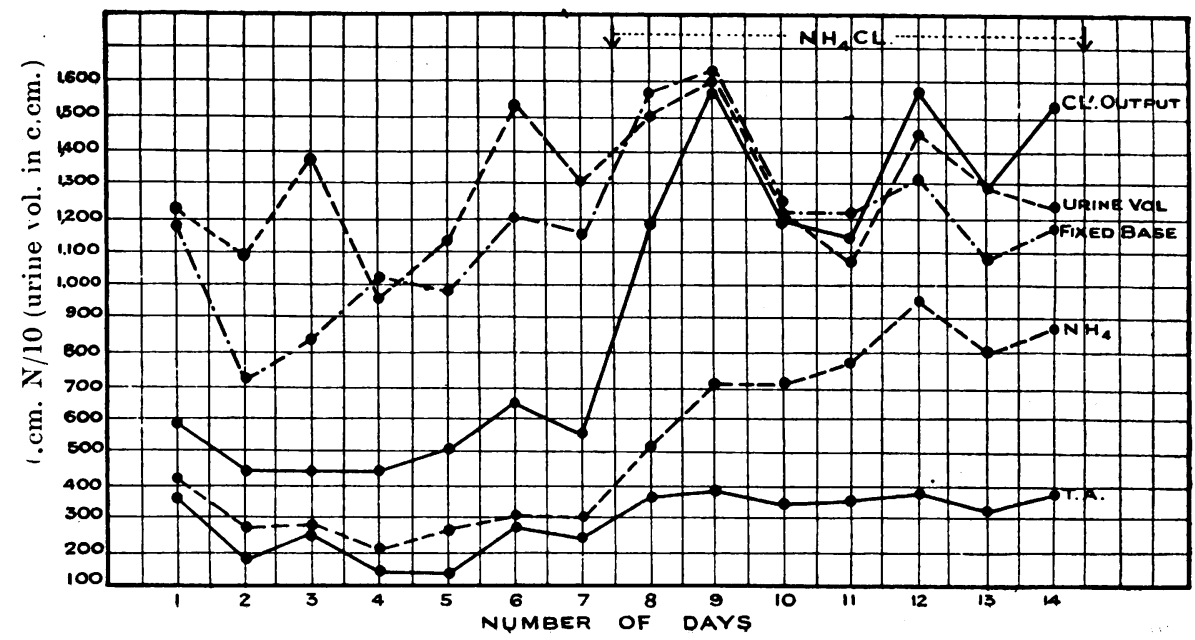


With the exception of N.M. the daily curve of $\mathrm{NaCl}$ output (Fig. 3-6) during administration of ammonium chloride shows that the peak of chloride excretion occurred on the second or third day. This was followed by a drop lasting over two or three days, which was succeeded on the fifth or sixth day by a peak reaching almost to the level of the first. In the case of N.M. there was a complete absence of the first peak but the second was quite marked. It will be noted in every case that this second peak corresponded with the maximum rise in the output of ammonia. It is therefore fair to conclude that this secondary rise in the excretion of chlorine was due to the increased ability of the kidney to supply ammonia. Indeed, a glance at the chlorine and ammonia curves following this second peak shows in every case a fairly marked parallelism indicating a correlation between these two substances. This parallelism is not noticeable during the first five days of ammonium chloride administration. There is also a fairly marked correlation between the amount of urinary chloride and fixed base both during the control and the ammonium chloride periods, with the exception of the control period of N.G. The urinary volume and chlorides also show some parallelism especially during the ammonium chloride periods.

Fig. 4. Case W. C. Graph showing dally urinary output of water, CHLORINE, FIXED BASE, AMMONIA AND TITRATABLF ACID.

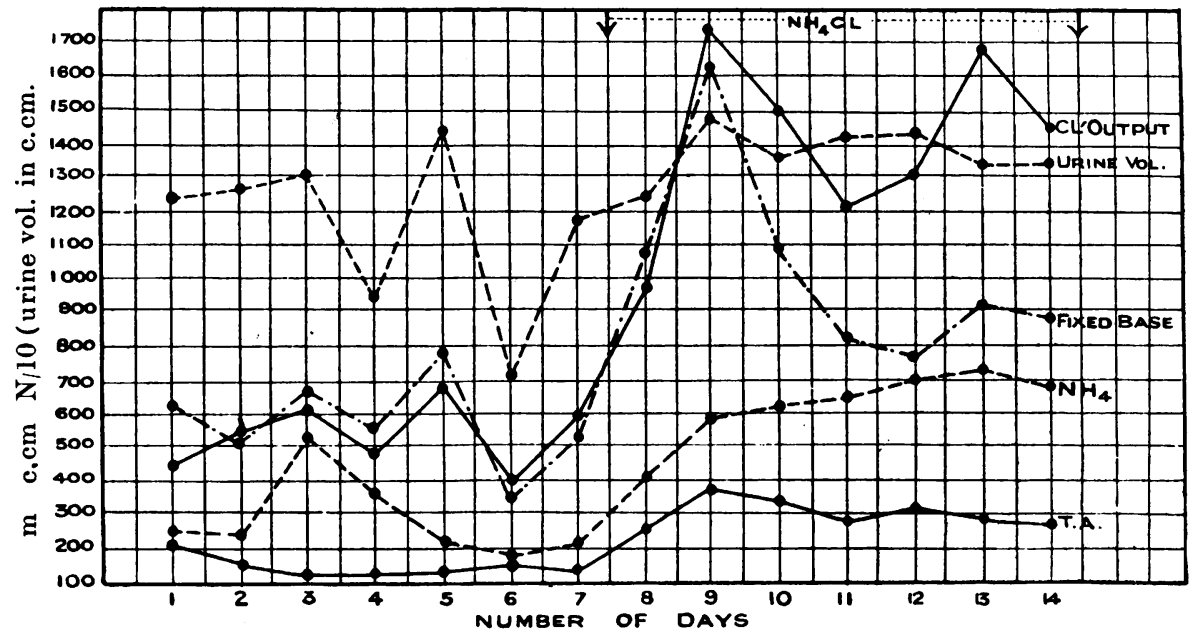

Urinary volume.-Gamble, Ross and Tisdall ${ }^{2}$ reported an increase of urinary volume in children during the administration of either calcium or ammonium chloride. Keith and Whelan ${ }^{11}$, however, found no change in the volume of urine excreted by a normal individual during ingestion of ammonium chloride. During such administration there was in all our cases except the first period of N.M. an increase in urinary volume, not, however, as marked as might have been expected. The daily output of urine varied greatly, frequently falling much below the maximum observed in the control period.

Ammonia and titratable acidity of the urine.-The output of ammonia and titratable acid was increased in every case during the administration of ammonium chloride. The maximum output of titratable acid was reached 
by the second day, following which there was usually a very gradual decline in the output. The ammonia content of the urine did not attain its greatest value till the 5th or 6th day, and in the case of J.F. the 9th day. Thereafter the output of ammonia remained at a constant level, except in the case of N.M. where considerable variations were observed from day to day. The ammonia output was not estimated in the days following the ammonium chloride period, but Gamble and others have shown that the output remains definitely above normal for some days following the administration of an acid salt.

TABLE 8.

Showing INTAKE, lRINARY AND FæCAL OUTPUTS ANI RETENTION OF FIXEl) BASE (C.CM. N/10 MONOVALENT BASE).

\begin{tabular}{|c|c|c|c|c|c|c|c|c|}
\hline \multirow[t]{2}{*}{ Name } & \multirow{2}{*}{\multicolumn{2}{|c|}{ Period }} & \multirow[t]{2}{*}{ Intake } & \multicolumn{3}{|c|}{ Output } & \multicolumn{2}{|c|}{ Retention } \\
\hline & & & & Urine & Fæces & Total & Total & $\begin{array}{c}\text { Per kgrm. } \\
\text { per day }\end{array}$ \\
\hline \multirow[t]{2}{*}{ N.G. } & Normal & $\ldots$ & 16254 & 7172 & 4561 & 11733 & 4521 & $24 \cdot 5$ \\
\hline & $\mathrm{NH}_{4} \mathrm{Cl}$ & ... & 16254 & 9105 & 5397 & 14502 & 1752 & $9 \cdot 4$ \\
\hline \multirow[t]{2}{*}{ W.C. } & Normal & $\ldots$ & 16254 & $\tilde{5} 442$ & 6579 & 12021 & 4233 & $22 \cdot 4$ \\
\hline & $\mathrm{NH}_{4} \mathrm{Cl}$ & .. & 16254 & 8434 & 6695 & 15129 & 1125 & $6 \cdot 0$ \\
\hline \multirow[t]{3}{*}{ J.F. } & Normal & ... & 10836 & 4494 & 4135 & 8629 & 2207 & $18 \cdot 1$ \\
\hline & $\mathrm{NH}_{4} \mathrm{Cl}$ & $\ldots$ & 10836 & 5465 & 5036 & 9501 & 1335 & $11 \cdot 0$ \\
\hline & $\mathrm{NH}_{4} \mathrm{Cl}$ & $\ldots$ & 10836 & 5841 & 4069 & 9910 & 926 & $7 \cdot 5$ \\
\hline \multirow[t]{3}{*}{ N.M. } & Normal & $\ldots$ & 15803 & 5726 & $5 \overline{5} 63$ & 11289 & 4514 & $21 \cdot 5$ \\
\hline & $\mathrm{NH}_{4} \mathrm{Cl}^{\prime}$ & $\ldots$ & 15803 & 8229 & 8039 & 16268 & -465 & $-2 \cdot 2$ \\
\hline & $\mathrm{NH}_{4} \mathrm{Cl}$ & .. & 11290 & 6616 & 7617 & 14233 & -2943 & $-19 \cdot 6$ \\
\hline
\end{tabular}

Fixed base.-The output of fixed base (Table 8) was with the exception of the control period of W.C., and the second ammonium chloride period of N.M., somewhat greater by the urine than by the fæces. The fæcal output of base was chiefly composed of calcium which constituted from 70 to 90 per cent. in the control periods and 77 to 99 per cent. in the ammonium chloride periods ('Table 9). Thus, not only did ammonium chloride increase the output of fixed base by the fæces, but it also raised the proportion of calcium to other base. In the urine the calcium formed $5 \cdot 4$ to $11 \cdot 1$ per cent. of the fixed base in the control periods and 11 to 15 per cent. in the test periods. The urine, therefore, showed during administration of ammonium chloride an increase in total fixed base, and a slight rise in the relative proportion of calcium to other base. The urinary fixed base reached its maximum within three days of the commencement of administration, thereafter falling to slightly above the average level of the control period. This is in agreement with the findings of Gamble, Blackfan and Hamilton ${ }^{8}$ with several acid-producing salts. The retention of fixed base varied from $18 \cdot 1$ to $24 \cdot 5 \mathrm{c.cm}$. N/10 per kgrm. of body 
TABLE 9.

SHOWING RELATIONSHIP OF OUTPUTS OF CALCIUM AND TOTAL FIXEI BASE.

\begin{tabular}{|c|c|c|c|c|c|c|c|c|c|}
\hline \multirow{3}{*}{$\begin{array}{l}\text { Name } \\
\text { N.G. }\end{array}$} & \multirow{2}{*}{\multicolumn{7}{|c|}{ Period }} & \multicolumn{2}{|c|}{$\begin{array}{c}\% \text { of calcium to output of } \\
\text { total fixed base }\end{array}$} \\
\hline & & & & & & & & Urine & Freces \\
\hline & $\begin{array}{l}\text { Normal } \\
\mathrm{NH}_{4} \mathrm{Cl}\end{array}$ & $\begin{array}{l}\cdots \\
\cdots\end{array}$ & $\begin{array}{l}\cdots \\
\cdots\end{array}$ & $\begin{array}{l}\cdots \\
\cdots\end{array}$ & $\begin{array}{l}\cdots \\
\cdots\end{array}$ & $\begin{array}{l}\cdots \\
\cdots\end{array}$ & $\begin{array}{l}\cdots \\
\cdots\end{array}$ & $\begin{array}{r}7 \cdot 0 \\
11 \cdot 5\end{array}$ & $\begin{array}{l}74 \cdot 3 \\
82 \cdot 4\end{array}$ \\
\hline W.C. & $\begin{array}{l}\text { Normal } \\
\mathrm{NH}_{4} \mathrm{Cl}\end{array}$ & $\begin{array}{l}\cdots \\
\cdots\end{array}$ & $\begin{array}{l}\cdots \\
\cdots\end{array}$ & $\begin{array}{l}\cdots \\
\cdots\end{array}$ & $\begin{array}{l}\cdots \\
\cdots\end{array}$ & $\begin{array}{l}\cdots \\
\cdots\end{array}$ & $\begin{array}{l}\cdots \\
\cdots\end{array}$ & $\begin{array}{l}10 \cdot 0 \\
11 \cdot 0\end{array}$ & $\begin{array}{l}89 \cdot 8 \\
99 \cdot 0\end{array}$ \\
\hline J.F. & $\begin{array}{l}\text { Normal } \\
\mathrm{NH}_{4} \mathrm{Cl} \\
\mathrm{NH}_{4} \mathrm{Cl}\end{array}$ & $\begin{array}{l}\cdots \\
\cdots \\
\cdots\end{array}$ & $\begin{array}{l}\cdots \\
\cdots \\
\cdots\end{array}$ & $\begin{array}{l}\cdots \\
\cdots \\
\cdots\end{array}$ & $\begin{array}{l}\cdots \\
\cdots \\
\cdots\end{array}$ & $\begin{array}{l}\cdots \\
\cdots \\
\cdots\end{array}$ & $\begin{array}{l}\cdots \\
\cdots \\
\cdots\end{array}$ & $\begin{array}{r}5 \cdot 4 \\
14 \cdot 0 \\
12 \cdot 8\end{array}$ & $\begin{array}{l}74 \cdot 1 \\
79 \cdot 0 \\
77 \cdot 5\end{array}$ \\
\hline N.M. & $\begin{array}{l}\text { Normal } \\
\mathrm{NH}_{4} \mathrm{Cl} \\
\mathrm{NH}_{4} \mathrm{Cl}\end{array}$ & $\begin{array}{l}\cdots \\
\cdots \\
\cdots\end{array}$ & $\begin{array}{l}\cdots \\
\cdots \\
\cdots\end{array}$ & $\begin{array}{l}\cdots \\
\cdots \\
\cdots\end{array}$ & $\begin{array}{l}\cdots \\
\cdots \\
\cdots\end{array}$ & $\begin{array}{l}\cdots \\
\cdots \\
\cdots\end{array}$ & $\begin{array}{l}\cdots \\
\cdots \\
\cdots\end{array}$ & $\begin{array}{l}11 \cdot 1 \\
13 \cdot 8 \\
15 \cdot 0\end{array}$ & $\begin{array}{l}70 \cdot 1 \\
87 \cdot 6 \\
83 \cdot 3\end{array}$ \\
\hline
\end{tabular}

weight per day during the control periods. It was always diminished during ammonium chloride administration, and was negative during both the periods of N.M., the loss being entirely accounted for by calcium.

\section{Metabolic reactions to acidosis.}

Against the production of a non-gaseous acidosis such as is produced by ammonium chloride the organism has the following general defences:--(1) an increase in the available base of the blood; (2) an increased excretion of volatile acid by the lungs ; and (3) an increased supply of base for neutralizing acids that are to be excreted.

(1) Increase in available base of the blood.-The fixed base is maintained at a fairly constant level. By a reduction in the $\mathrm{CO}_{2}$ content of the

Fig. 5. Case .J. F. Graph Showing dally lkiNaky oUtput of water CHLORINE, FIXED BASE, AMMONIA AND TITRATARLE ACID.

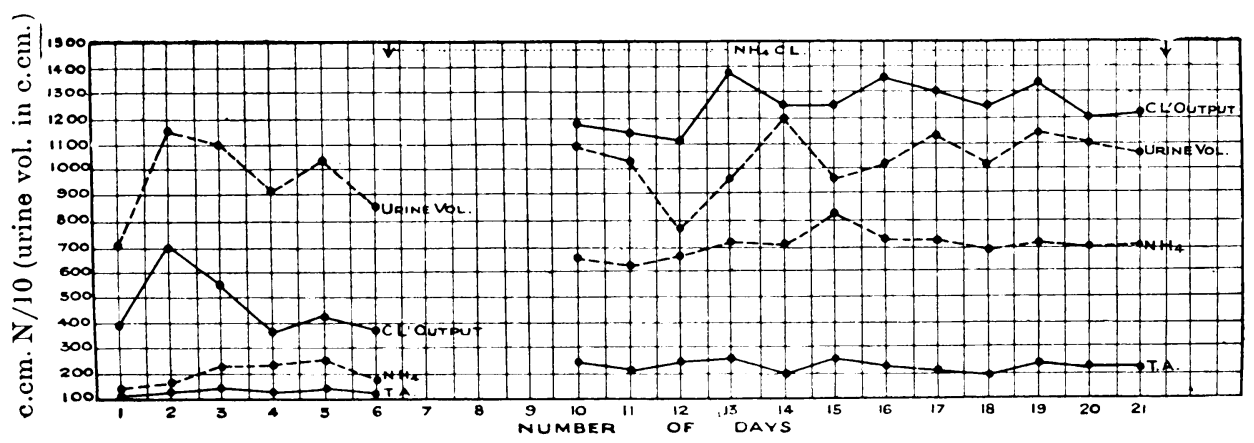


blood a certain amount of base is freed and rendered available for the neutralization of other acid radicles. It has been shown that the base-combining powers of protein and inorganic phosphorus are reduced with a fall in the $\mathrm{pH}$ of the blood, but the amount of base released by these changes in such a condition as prevails in the experiments detai ed here is practically negligible. The fall in blood- $\mathrm{CO}_{2}$, therefore, undoubtedly constitutes the chief immediate response to acidosis of the non-gaseous variety. In the subjects of this study the increase in available base produced by the reduction in $\mathrm{CO}_{2}$ could not have amounted to more than $230 \mathrm{c.cm}$. N/10 (on the assumption that the bloodvolume was one-thirteenth of the body weight). One gramme of ammonium chloride (i.e., one-fifth of the daily intake) contains $187 \mathrm{c.cm} . \mathrm{N} / 10$ acid. Two such doses are therefore much more than sufficient to use up all the base made available by the reduction in $\mathrm{CO}_{2}$. The relief afforded by this means is only temporary, since prolonged administration of ammonium chloride does not to any extent further reduce the $\mathrm{CO}_{2}$ content of the blood. The state of affairs produced in our subjects corresponds according to the nomenclature of Van Slyke to the condition of compensated acidosis (i.e., a fall in bicarbonate without symptoms of acidosis or change in the $\mathrm{pH}$ of the blood.) Although the $\mathrm{pH}$ was not actually estimated it is safe to assume that the absence of

Fig. 6. Case N.M. (ikaph showisg dally output of water CHIORINR, FIXED BASE, AMMONIA, AND TITRATABLE ACID.

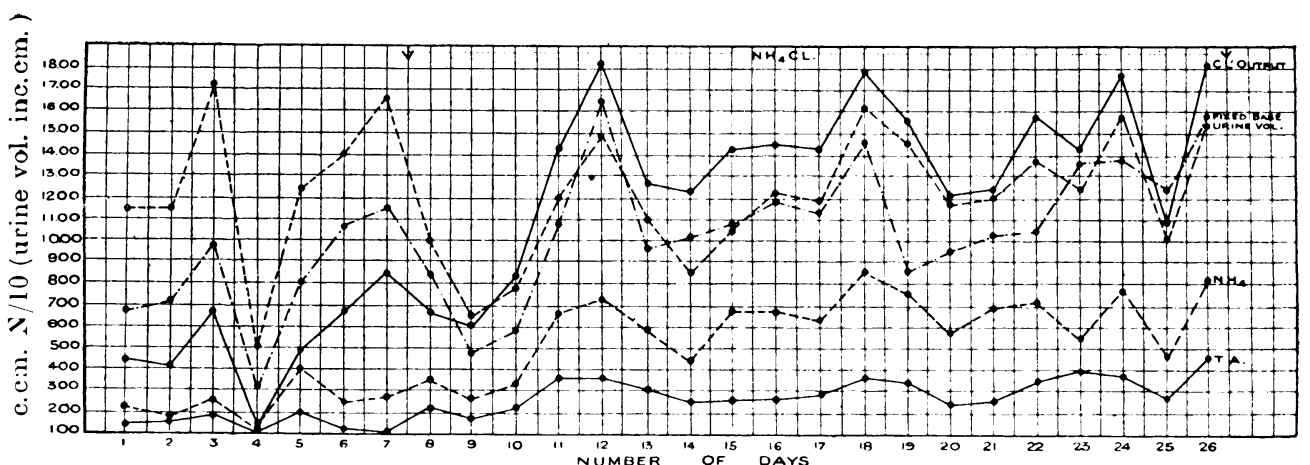

noticeable respiratory changes indicated an absence of any change in the $\mathrm{pH}$ of the blood that would be detected by physico-chemical means.

In clinical acidosis figures for total $\mathrm{CO}_{2}$ have been noted much lower than the lowest in the present series. Such low figures supply definite evidence of an inability of the other compensatory mechanisms to deal with the situation either because of the suddenness of the demands (as in Haldane's case with an avalanche of $25 \mathrm{grm}$. of ammonium chloride), or because of the functional inefficiency, relative or absolute, of the other defensive reactions, as in diabetic or uræmic coma.

(2) Increased excretion of volatile acids by the lungs.-Respiratory changes leading to an insreased output of $\mathrm{CO}_{2}$ must naturally follow the displacement of $\mathrm{CO}_{2}$ from its union with base. Otherwise the tension of $\mathrm{CO}_{2}$ in the blood would increase and lead to the production of a $\mathrm{CO}_{2}$ acidosis 
(gaseous). In our cases, as would be expected from the results of the $\mathrm{CO}_{2}$ analyses of the blood, there were no marked respiratory alterations. The excretion of the extra $\mathrm{CO}_{2}$ must have been of such relatively small amount that no apparent strain was put on the respiratory system.

(3) Supply of base for the excretion of acid.-The kidney is undoubtedly the principal organ for the excretion of the non-volatile acid radicles. The sweat glands may play an important part in the metabolism of chlorine when large amounts of sweat are produced, although Schwenkenbecker and Spitta ${ }^{24}$ conclude that not more than one gramme of sodium chloride is excreted daily even during profuse sweating. In the absence of hyperidrosis, at any rate, it is justifiable to assume that the amount of electrolyte lost in this way is practically negligible. The bowel certainly plays a part in mineral metabolism, but as far as the actual excretion of chlorine is concerned the intestinal output is negligible. Accordingly we may conclude that the extra acid supplied in these experiments must have been excreted by the kidneys.

At the lowest possible value of the urinary $\mathrm{pH}$ chlorine cannot be excreted as a free acid, requiring therefore a full equivalence of base. This base can be obtained in three ways. (a) Base may be released from weak acids which can be excreted either free or with only a partial complement of base. (b) Extra ammonia may be formed. (c) Fixed base may be supplied from the tissues and tissue-fluids.

(A) RELEASE OF BASE FROM WEAK ACIDS.-This is, of course, an accompaniment, if not the result, of increased acidity of the urine, which decreases the base-combining powers of the weaker acids. Change of phosphate from the mono-hydrogen to the di-hydrogen variety forms the best example of the saving of base effected in this way.

If we assume that during the control period the $\mathrm{pH}$ of the urine was $6 \cdot 81$, and during the $\mathrm{NH}_{4} \mathrm{Cl}$ period 5.91, the amount of base saved by change of phosphate from $\mathrm{Na}_{2} \mathrm{HPO}_{4}$ to $\mathrm{NaH}_{2} \mathrm{PO}_{4}$ may be calculated as follows :-

at $\mathrm{pH} 6 \cdot 81-50$ per cent. of phosphorus is in the form of $\mathrm{NaH}_{2} \mathrm{PO}_{4}$

$0 \%$ " $5 \cdot 9190, \%$

Of $1000 \mathrm{mgrm}$. phosphorus.

at $\mathrm{pH} 6.81500 \mathrm{mgrm}$. are present as $\mathrm{NaH}_{2} \mathrm{PO}_{4}$

," ,5.91 $900 \quad$, ,, ,, ,

In changing, therefore, from $\mathrm{pH} 6.81$ to $\mathrm{pH}, \overline{5} \cdot 91,400 \mathrm{mgrm}$. are converted from the mono-to the di-hydrogen variety. Since one $\mathrm{H}$-ion is involved in the change of each phosphate molecule it would require 1 litre of normal acid to change 1 litre of normal phosphorus (i.e., $31 \mathrm{grm}$. phosphorus) from the mono-to the di-hydrogen phosphate.

To change $400 \mathrm{mgrm}$. P. would require $\frac{0 \cdot 400 \times 1000}{31}$ c.cm. N/1 acid, (i.e., $13 \mathrm{c.cm}$. N/10 acid).

By change of urinary $\mathrm{pH}$ from 6.81 to 5.91 there will be a saving of $130 \mathrm{c.cm}$. $\mathrm{N} / 10$ base per every gramme of phosphorus excreted.

This saving is indicated by the increase in titratable acidity. The response of the urinary system in this direction reaches its maximum within a very short time of the commencement of ammonium chloride administration. The base so released amounts, however, to only a small part of that likely to be required in any but the very mildest forms of increased acid excretion, and it certainly would be hopelessly inadequate to meet the requirements of even the smallest degree of acidosis that could be recognised clinically. 
(B) Increase in ammonia Formation.-The work of Benedict and Nash ${ }^{25}$ has shown that ammonia is formed in the kidney. In cases of marked renal inefficiency tho ammonia output is low : this must play an important part in the production of renal acidosis. In the subject with normal renal function the supply of ammonia forms a most important bulwark against acidosis. The increase in ammonia formation takes some time to reach its maximum. Some mechanism is therefore required to tide over the needs of the excretory system for more base until the supply of ammonia is sufficient to meet the demands. This mechanism will be discussed in the next section, but before leaving the question of increased ammonia production it is well to remember that the increase in ammonia output is continued after the need for increased acid excretion has ceased. As Gamble and his co-workers have pointed out this continued formation of ammonia is of vital importance in restoring the depleted stores of body base to normal.

(c) SUPPly OF FIXed BASE FROM tissces and TISSUE-Fluids.-This method provides the chief immediate means whereby excess anions are excreted. The base may be derived from the bones or from the other tissues in which latter case it must be accompanied by fluid in order to prevent disturbances of osmotic equilibrium.

In the bones calcium is found as phosphate with a small amount of carbonate. Accordingly the release of calcium entails the freeing of phosphorus which must also be excreted. In this transaction, however, there is a distinct saving of base. In bone two equivalents of phosphorus neutralize three equivalents of calcium (i.e., six equivalents of monovalent base). As excreted, however, the phosphorus in the urine is monovalent while in the fæces it has probably about the same valency as in the plasma, namely, 1·8. Accordingly for every equivalent of bone phosphorus excreted in the urine we have the saving of two equivalents of base, while for every equivalent in the fæces the saving effected is $1 \cdot 2(=3-1 \cdot 8)$.

If it is assumed that the excess of calcium excreted is derived in proportionately equal amounts from the carbonate and phosphate of the bone, then one-fifth of this excess comes from the carbonate. Therefore the amount of base rendered available by the release of calcium carbonate may be calculated as the equivalents of monovalent base contained in one-fifth of the total excess calcium found in the excreta. The amount of base obtained from the phosphate may be calculated from the excess phosphorus as follows :-

(Excess urinary $\mathrm{P}$. in c.cm. $\mathrm{N} / 10 \times 2)+($ Excess fæcal P. in c.cm. $\mathrm{N} / 10 \times 1 \cdot 2)$.

It may be objected that not all of the extra calcium and phosphorus come from bone. As the calcium content of the non-osseous tissues is relatively minute, bone must form the chief source of calcium. Phosphorus, however, plays an important part quantitatively in practically all metabolic processes. In three of our cases there was more extra phosphorus than extra calcium found in the excreta, thus showing that bone is not the source of all the extra phosphorus. The amount of extra phosphorus excreted from the extraosseous source must form, however, only a small fraction of the total, and can only modify slightly the saving of base as calculated from the above formula. 
The fixed base from the non-osseous tissues consists almost entirely of sodium and potassium, the former derived chiefly from extra-cellular, the latter being mainly an intra-cellular constituent. In either case, however, the base is associated with an equivalent amount of acid. If this base is excreted, some means must be found for dealing with its anions. Of these $\mathrm{CO}_{2}$ is excreted by the lungs, while protein which holds about ten equivalents of base is probably katabolized. With the exception possibly of some of the organic acid, the remaining anions demand their full quota of base for neutralizing purposes. The water carrying the base must also be got rid of in order to prevent an upset of osmotic equilibrium. Accordingly for every $150 \mathrm{c.cm} . \mathrm{N} / 10$ base there will be rendered available only about $40 \mathrm{c.cm} . \mathrm{N} / 10$ for neutralizing extra acid. This $40 \mathrm{c.cm}$. is made up of $24 \mathrm{c.cm}$. from $\mathrm{B} . \mathrm{HCO}_{3}$ and the remainder from $B$. protein and organic salts. The efficiency in supplying base is thus only 26 per cent., even when blood plasma is the fluid called upon, and must be less in the case of the tissue-juices where the protein content is lower. Accompanying this $150 \mathrm{c.cm}$. N/10 base will be $100 \mathrm{c.cm}$. water which will contain its normal quota of fixed acid $\left(\mathrm{Cl}^{\prime}, \mathrm{SO}^{\prime \prime}{ }_{4}\right)$. The amount of tissue fluid excreted during the ammonium chloride period is indicated by the increase in urinary volume. The chlorine content of this excess in urinary volume should, if the hypothesis put forward be correct, approximate to that of the plasma.

TABLE 10.

Showing the means haployed in neutralising the excess acid.

\begin{tabular}{|c|c|c|c|c|c|c|c|c|c|}
\hline \multirow{3}{*}{ Name } & (1) & (2) & (3) & $(4)$ & $(5)$ & (6) & \multirow{3}{*}{\begin{tabular}{c}
\multicolumn{1}{c}{$(7)$} \\
Tissue \\
fluid \\
base
\end{tabular}} & \multirow{3}{*}{\begin{tabular}{l}
\multicolumn{1}{c}{$(8)$} \\
Incr. in \\
urinary \\
volume
\end{tabular}} & $(9)$ \\
\hline & \multirow{2}{*}{$\begin{array}{l}\text { Incr. } \\
\text { in } \\
\mathrm{Cl}^{\prime}\end{array}$} & \multirow{2}{*}{$\begin{array}{l}\text { Incr. } \\
\text { in } \\
\text { T.A. }\end{array}$} & \multirow{2}{*}{$\begin{array}{l}\text { Iner. } \\
\text { in } \\
\mathrm{NH}_{4}\end{array}$} & \multicolumn{3}{|c|}{ Incr. base derived from } & & & Calculated \\
\hline & & & & $\mathrm{CaCO}_{3}$ & $\begin{array}{c}\text { Fæcal } \\
\mathrm{P}^{\prime}\end{array}$ & $\begin{array}{c}\text { Urinary } \\
\mathrm{P}^{\prime}\end{array}$ & & & $\begin{array}{c}\text { B.Cl per } \\
100 \text { c.cm. } \\
\text { excess } \mathrm{H}_{2} \mathrm{O}\end{array}$ \\
\hline N.G. & 5933 & 917 & 3298 & 320 & 370 & 192 & 837 & 850 & $98 \cdot 4$ \\
\hline W.C'. & 6038 & 1172 & 2452 & 145 & 30 & 896 & 1343 & 1475 & $91 \cdot 1$ \\
\hline J.F. & 4470 & 527 & 3051 & 285 & 355 & 36 & 216 & 231 & $93 \cdot 5$ \\
\hline & 4827 & 503 & 3670 & 116 & 40 & nil & 498 & 526 & $94 \cdot 7$ \\
\hline N.M. & 6334 & 1150 & 2768 & 721 & 1340 & 236 & $121^{*}$ & nil & - \\
\hline
\end{tabular}

*This amount of fixed base was probably supplied without the accompaniment of fluid by the reduction of the fixed base content of the blood by $15 \mathrm{c.cm}$. N/ 10 per $100 \mathrm{c.cm}$.

In Table 10 are given the figures indicating the methods whereby the excess of excreted acid (chlorine) has been neutralized. Column 1 gives the values for the excess excretion of chlorine. Columns 2 to 7 indicate the amount of base derived from the sources indicated for the neutralization of this excess chlorine. The figures in columns 2 to 6 are calculated from the 
results of the analyses, but those in column 7 have been obtained as follows :$\mathrm{Cl}-$ (T.A. $+\mathrm{NH}_{4}+$ Base derived from bone). Our results do not contain values for sulphates and organic acids which, as has been shown by Gamble, are also excreted in excess during acidosis. These acid radicles probably come from tissue juices and carry down with them their quota of base from the tissue-juices. Thus by calculating the figures in column 7 in the manner stated, we obviate any error due to the presence of excess sulphates. The base figures given in column 7 indicate the amount of tissue-fluid base combined with chlorine, in other words the amounts of B.Cl. Accordingly if these figures are divided by the corresponding increase in urinary volume (column 8) the results obtained should give the value for the percentage of $\mathrm{B}$.Cl. in the tissue fluid (column 9). It is evident that these values lie between 90 and 100 , therefore within the normal limits of chlorine in plasma and presumably in tissue juice. Despite the fact that the method of calculation is and must be one of comparatively rough averages, we feel that the consistency of the values so obtained is sufficiently striking to afford strong support to the thesis which has been advanced.

Several further points may be noted. If the view proposed is correct, one would have expected that the bulk of the excess phosphorus would have been excreted in the urine, since output by the kidneys effects a saving of two equivalents of base per equivalent of phosphorus, whereas for fæcal excretion the economy achieved is only $1 \cdot 2$. The fact that the bulk of the excess phosphorus is not excreted in the urine is probably related to the fact that there is a close association between the calcium and phosphorus in the fæces.

Administration of hydrochloric acid has been shown to increase the urinary output of phosphorus. This has been attributed to a change of reaction in the intestinal lumen producing a better absorption of phosphorus. In the light of our results, which also show an increased fæcal excretion, it would seem reasonable to refer both the increased urinary and fæcal excretion to the necessity for providing more base in the manner indicated.

Another point of interest is the different extent to which the various mechanisms are brought into play in reacting to excess acid. For the immediate supply of base both bone and tissue-juices are called upon. The one exception to this is the ammonium chloride period of N.M., where practically all the necessary fixed base was derived from bone; less urine was passed than in the control period indicating a lack of response on the part of the tissue fluids. As to the rapidity with which the osseous tissue responds to the stimulus of an acidosis we have no data. H. L. White ${ }^{26}$ obtained an increased urinary output of phosphorus within four hours of the administration of acid, but considered this merely a temporary phenomenon. Haldane, Hill and $\operatorname{Luck}^{27}$, however, found a definite increase in the urinary output of phosphorus for 24 hours following the ingestion of large amounts of $\mathrm{CaCl}_{2}$. On the other hand Gamble, Blackfan and Hamilton ${ }^{8}$ observed no significant change in phosphorus excretion after the intake of moderately large amounts of acid. 


\section{Summary.}

1. The effect of prolonged administration of ammonium chloride on the metabolism was studied in four apparently normal children, in none of whom was produced any clinical manifestation of acidosis.

2. Chemical changes in blood. (a). The $\mathrm{CO}_{2}$ was reduced; the reduction almost always reached its maximum early in the administration of ammonium chloride.

(b). The chlorine was moderately increased. The increase in chlorine did not exactly balance the deficiency in $\mathrm{CO}_{2}$.

(c). The fixed base remained within normal limits except in one case where it was reduced by 15 milli-equivalents.

(d). The calcium was slightly increased and the phosphorus slightly diminished. limits.

(e). The non-protein nitrogen was slightly increased but within normal

3. Metabolism. (a). There was an increased output of calcium both by urine and fæces and consequently a decreased retention. Evidence is adduced in favour of the excretion of calcium through the bowel wall.

(b). There was an increased excretion of phosphorus by urine and fæces and a diminished retention.

(c). There was a slightly increased retention of chlorine. There were usually two peaks in the excretion of chloride : they occurred about the second and sixth days. The second peak usually coincided with the maximum output of ammonia.

(d). There was an increased excretion of fixed base both by urine and fæces. The extra fæcal base consisted chiefly of calcium.

4. The metabolic reactions to acidosis are discussed, and it is suggested that the increase in the output of calcium and phosphorus is the result of the response of the osseous tissues and forms a reaction of prime importance in the defence of the organism to acidosis. Evidence is brought forward from the result of the study in support of this thesis.

We desire to express our thanks to the Medical Research Council for assistance in this work, and for a personal grant to one of us (N.M.).

Analytical methods used :-Total $\mathrm{CO}_{2}-$ Haldane: Chlorine-Whitehorn : Non-protein nitrogen-Folin and $\mathrm{Wu}$ : Fixed base-Stadie and Ross : Calcium-Kramer and Tisdall : Phosphorus-Tisdall : Titratable acidity of urine-using phenolphthalein as indicator.

\section{REFERENCES.}

1. Haldane, J. B. S., J. Physiol., Lond., 1921, LV, 265.

2. Steenbock, H., Nelson, M. V., \& Hart, E. B., J. Biol. Chem., Baltimore, 1914, XIX, 399.

3. Sawyer, M., Baumann, L., \& Stevens, F., Ibid., 1918, XXXIII, 103.

4. Bogert, L. J., \& Kirkpatrick, E. E., Ibid., 1922, LIV, 375.

5. Flood, R. S., Amer. J. Dis. Child., Chicago, 1926, XXXII, 550.

6. Freudenberg, E., \& György, P., Münch. med. Woch., München, 1922, XII, 422.

7. Gamble, J. L., Ross, S. G., \& Tisdall, F., Am. J. Dis Child., Chicago, 1923, XXV, 455.

8. Gamble, J. L., Blackfan, K. D., \& Hamilton, B., J. Clin. Investig., Baltimore, 1925, I, 329, 
9. Folling, A., Acta. Med. Scand., Stockholm, 1929, LXXI, 221.

10. Koehler, A. E., J. Biol. Chem., Baltimore, 1927, LXXII, 99.

11. Keith, N. M., \& Whelan, M., J. Clin. Investig., Baltimore, 1926-7, III, 149.

12. Baird, M. M., Douglas, C. G., Haldane, J. B. S., \& Priestley, J. G., Proc. Physiol. Soc. p. xli, J. Physiol., Lond., 1923, LVII.

13. Stewart, C. P., \& Haldane, J. B. S., Biochem. J., Lond., 1924, XVIII, 856.

14. Haldane, J. B. S., Wigglesworth, V. B., \& Woodrow, C. F., Proc. Roy. Sor. B., Lond., 1924, XCVI, 1.

15. Goto, K., J. Biol. Chem., Baltimore, 1918, XXXVI, 355.

16. Grosser, P., Ztschr. f. Kinderh., Berlin, 1920, XXV, 141.

17. Salvesen, H. A., J. Biol. Chem., Baltimore, 1923, LVI, 443.

18. Percival, G. H., \& Stewart, C. P., Biochem. J., Lond., 1927, XXI, 301.

19. Bauer, W., Albright, F., \& Aub, J. C., J. Clin. Investig., Baltimore, 1929, VII, 7.).

20. Givens, M. H., \& Mendel, L. B., J. Biol. Chem., Baltimore, 1917, XXXI, 421.

21. Nelson, M. V., Am. J. Dis. Child., Chicago, 1928, XXXVI, 716.

22. Shohl, A. T., \& Sato, A., J. Biol. Chem., Baltimore, 1923, LVIII, 235.

23. Telfer, S. V., Quart. J. Merl., Oxford, 1922, XVI, 63.

24. Schwenckenbecker \& Spitta., Arch. f. Exp. Path. u. Pharm., Leipzig, 1907, LVI, 284.

25. Benedict, S. R., \& Nash, T. P., J. Biol. Chem., Baltimore, 1926, LXIX, 381.

26. White, H. L., Amer. J. Physiol., Baltimore, 1927, LXXX, 82.

27. Haldane, J. B. S., Hill. R., \& Luck, J. M., J. Physiol., Lond., 1923, LVII, 301. 